\title{
The relative merits of therapies being developed to tackle inappropriate ('self'-directed) complement activation
}

\author{
Samuel Antwi-Baffour ${ }^{1} \cdot$ Ransford Kyeremeh $^{1} \cdot$ Jonathan Kofi Adjei $^{1}$ • \\ Claudia Aryeh ${ }^{1} \cdot$ George Kpentey $^{1}$
}

Received: 9 October 2015 / Accepted: 3 February 2016/Published online: 3 March 2016

(C) The Author(s) 2016

\begin{abstract}
The complement system is an enzyme cascade that helps defend against infection. Many complement proteins occur in serum as inactive enzyme precursors or reside on cell surfaces. Complement components have many biologic functions and their activation can eventually damage the plasma membranes of cells and some bacteria. Although a direct link between complement activation and autoimmune diseases has not been found, there is increasing evidence that complement activation significantly contributes to the pathogenesis of a large number of inflammatory diseases that may have autoimmune linkage. The inhibition of complement may therefore be very important in a variety of autoimmune diseases since their activation may be detrimental to the individual involved. However, a complete and long-term inhibition of complement may have some contra side effects such as increased susceptibility to infection. The site of complement activation will, however, determine the type of inhibitor to be used, its route of application and dosage level. Compared with conventional drugs, complement inhibitors may be the best option for treatment of autoimmune diseases. The review takes a critical look at the relative merits of therapies being developed to tackle inappropriate complement activation that are likely to result in sporadic autoimmune diseases or worsen already existing one. It covers the complement system, general aspects of complement inhibition therapy, therapeutic strategies and examples of
\end{abstract}

Samuel Antwi-Baffour

antwibaffour@msn.com; s.antwi-baffour@chs.edu.gh

1 Department of Medical Laboratory Sciences, School of Allied Health Sciences, College of Health Sciences, University of Ghana, P. O. Box KB 143, Korle-Bu, Accra, Ghana complement inhibitors. It concludes by highlighting on the possibility that a better inhibitor of complement activation when found will help provide a formidable treatment for autoimmune diseases as well as preventing one.

Keywords Complement - Activation - Inhibitors · Autoimmune diseases · Therapy

\section{Introduction}

The role of complement in human diseases, particularly autoimmune diseases, was relatively unknown some time ago, but with increasing evidence that complement activation significantly contributes to the pathogenesis of a large number of inflammatory diseases, strategies that interfere with its deleterious action have become a major focus in pharmacological research $[1,2]$.

Attempts to efficiently inhibit complement include the application of endogenous soluble complement inhibitors (C1-inhibitor, recombinant soluble complement receptor 1-r sCR1), the administration of antibodies, either blocking key proteins of the cascade reaction (e.g., C3, C5), neutralizing the action of the complement-derived anaphylatoxin C5a, or interfering with complement receptor 3 (CR3, CD18/11b)-mediated adhesion of inflammatory cells to the vascular endothelium $[3,4]$.

In addition, incorporation of membrane-bound complement regulators (decay accelerating factor-DAF-CD55, Membrane Cofactor Protein-MCP-CD46, CD59) has become possible by transfection of the correspondent cDNA into xenogeneic cells [5]. These complement inhibitors target specific complement activators and prevent them from initiating activation and if activation is underway, stop it from continuing $[6,7]$. 


\section{Autoimmune disease}

Autoimmune diseases remain a major health problem despite enormous efforts to understand the underlying causative mechanisms [8]. The lack of clarity with regard to both the predisposing factors and the precise antigenic targets of the immune response has restricted the development of effective therapeutic approaches [9]. Autoimmune diseases are a result of loss of tolerance where an organism fails to recognize its own constituent parts as "self" [1]. An essential prerequisite for the pathogenesis of autoimmune diseases is indeed the breakage of immunological tolerance, leading to the immune system mounting an effective and specific immune response against self determinants $[10,11]$. Several theories have been proposed since the mid-twentieth century to explain the origin of the exact genesis of immunological tolerance [10-12].

These include: coral deletion theory where self-reactive lymphoid cells are destroyed during the development of the immune system, Anergy theory where self-reactive $\mathrm{T}$ or B-cells become inactivated in the normal individual and cannot amplify the immune response, and Idiotype Network theory, where a network of antibodies capable of neutralizing self-reactive antibodies exists naturally within the body [13-16]. There is genetic, sex, and environmental factors associated with autoimmune diseases [16, 17]. Human leukocyte antigen (HLA) DR2, DR3, DR4 have been shown to be strongly and positively correlated with some autoimmune diseases and negatively correlate others [17]. Sex also seems to have a major role in the development of autoimmunity with most of the known autoimmune diseases tending to show a female preponderance whilst in areas where multiple infectious diseases are endemic, autoimmune diseases are quite rarely seen [18]. Certain chemical agents and drugs can also be associated with the genesis of autoimmune conditions, or conditions which simulate autoimmune diseases [19].

Autoimmune diseases can be broadly divided into systemic and organ-specific or localized autoimmune disorders, depending on the principal clinical pathologic features of each disease $[1,8]$. Systemic syndromes include systemic lupus erythematosus (SLE), Sjogren's syndrome, Scleroderma, Rheumatoid Arthritis and polymyositis. Local syndromes may be endocrinologic (insulin-dependent diabetes mellitus-IDDM, Hashimoto's thyroiditis, Adddison's disease etc.), haematologic (autoimmune haemolytic anaemia), neural (multiple sclerosis) or can involve virtually any circumscribed mass of body tissue [1, $8,11,16]$.

The different autoimmune diseases can each affect the body in different ways $[1,8]$. For example, the autoimmune reaction is directed against the brain in multiple sclerosis and the gut in Crohn's disease [20, 21]. In other autoimmune diseases such as SLE (lupus), affected tissues and organs may vary among individuals with the same disease [16]. One person with lupus may have affected skin and joints, whereas another may have affected skin, kidney and lungs [16]. Ultimately, damage to certain tissues by the immune system may be permanent as with destruction of insulin-producing cells of the pancreas in Type 1 diabetes mellitus [22].

Autoimmune diseases represent a class of diseases which are often difficult to treat effectively [23]. Although there are a number of drugs which exist to treat them, none are adequate to control or inhibit the disease progression $[23,24]$. The inhibition of complement may be very important in a variety of autoimmune diseases because as the complement system becomes active, there may be destruction and removal of cells and substances, which may be detrimental to the individual [3]. It is useful, therefore, to have substances which can be administered to patients to prevent active complement activation thereby preventing autoimmune diseases from occurring [3, 23, 25].

\section{The complement system}

The complement system is a complex system containing more than 30 various glycoproteins present in serum in the form of components, factors or other regulators and/or on the surface of different cells in the form of receptors [26]. These are produced constitutively by macrophages and hepatocytes, and are present in the circulation as inactive molecules until they are cleaved by a protease, which in turn converts them into a protease $[17,26]$. Several complement proteins are pro-enzymes and when activated become the proteases that cut peptide bonds in other complement proteins to activate them in turn [28]. Since each activated protease can activate many substrate molecules, the initial activation is rapidly amplified to produce millions of effector molecules in the form of a cascade [26$28]$.

There are actually three complement cascades [29]. They are activated by different molecules, but many of the component proteins are the same and all the effector functions are also the same [29]. The classical complement cascade, activated by antigen-bound $\operatorname{IgM}$ and $\operatorname{IgG}$, was discovered first; the alternative complement cascade is activated by bacteria cell surface molecules such as lipopolysaccharide (LPS) from Gram negative outer membranes, teichoic acid from Gram positive cell walls, zymosan from fungal and yeast cell walls, and some parasite surface molecules; then the mannose-binding lectin (MBL) cascade requiring synthesis of MBL by the liver in response to inflammatory macrophage cytokines [30-32]. 
Complement activation stimulates several antimicrobial activities [33]. The endpoint is the formation of a membrane attack complex (MAC), which inserts into lipid membranes of bacteria or eukaryotic cells and causes osmotic lysis [34]. Also Complement fragments called opsonins adhere to microorganisms and promote leukocyte chemoattraction, antigen binding and phagocytosis, and activation of macrophage and neutrophil killing mechanisms [30, 31, 34].

Complement activation also leads to the generation of a series of activation peptides that are capable of producing inflammation [35]. In addition, complement is thought to play a major role in the afferent limb of the immune response, increasing the immunogenicity of antigens with bound complement peptides [36]. It may also be important in eliminating clones of lymphocytes involved in the immune response to self antigens [37]. With the revelation that complement plays a crucial role in the pathogenesis of inflammatory tissue destruction, a great enthusiasm has evolved for specific complement inhibition as a novel treatment of human diseases $[3,5,6,38]$.

\section{The complement system in relation with autoimmunity}

In autoimmunity, tolerance to self molecules (antigens) is lost which results in the various autoimmune diseases. Loss of tolerance to complement factors is one of the mechanisms that results in an autoimmune disease such as atypical haemolytic uraemic syndrome (aHUS). aHUS is an extremely rare, life-threatening, progressive disease that frequently has a genetic component and in most cases caused by chronic, uncontrolled activation of the complement system [39]. The disease affects both children and adults and is characterized by systemic thrombotic microangiopathy (TMA) that leads to the formation of blood clots in small blood vessels throughout the body. This can lead to stroke, heart attack, kidney failure, and eventually death [39-41]. The complement system activation may be as a result of mutations in the complement regulatory proteins (factor $\mathrm{H}$, factor $\mathrm{I}$, or membrane cofactor protein) [41, 42], or is occasionally due to acquired neutralizing autoantibody inhibitors of the complement system components, for example anti-factor $\mathrm{H}$ antibodies [43]. Subsequently, tolerance to complement is lost in patients with aHUS and most of them demonstrate the chronic, uncontrolled and excessive activation of complement resulting from the production of the anti-factor $\mathrm{H}$ autoantibodies or genetic mutations in any of several complement regulatory proteins (e.g., factor $\mathrm{H}$, factor HR1 or HR3, membrane cofactor protein, factor I, factor B, complement C3, and thrombomodulin) [44]. The end result if this is platelet and white blood cell activation and damage to endothelial cells, leading to systemic TMA, which manifests as decreased platelet count, haemolysis, damage to multiple organs, and then death [45-47]. Despite the use of supportive care, historically an estimated 33-40\% of patients die or develop end-stage renal disease (ESRD) with the first clinical bout of aHUS [42].

\section{General aspects of complement inhibition therapy}

\section{Complement inhibition in human disease}

Several disease states such as immune complex and autoimmune diseases and genetic deficiencies of some complement regulators are associated with inappropriate activation of complement [48]. In some diseases, complement is activated for a long or indefinite period while in others for a comparatively short time; in some it is activated systemically, in others locally in tissue or organs; in some the whole complement cascade is activated, in others only a few components are activated $[31,33]$. In some, the classical pathway is activated whilst in others the alternative pathway $[31,33]$.

In many complement activating diseases, biological activities of complement fragments become detrimental, resulting in tissue injury and disease [48]. Inhibition of complement by specific inhibitors is therefore likely to arrest complement-mediated disease processes [3]. From this point of view, some laboratories are developing low molecular weight synthetic inhibitors, whereas others are developing natural or recombinant forms of high molecular weight inhibitors of complement present in plasma or on cell surfaces with the eventual aim of manipulating complement system in human diseases [49, 50].

\section{The complement cascade}

Complement activation involves three major steps or cascades: activation of a $\mathrm{C} 3$ convertase to cut $\mathrm{C} 3$ into $\mathrm{C} 3 \mathrm{a}$ and $\mathrm{C} 3 \mathrm{~b}$; activation of a $\mathrm{C} 5$ convertase to cut $\mathrm{C} 5$ into $\mathrm{C} 5 \mathrm{a}$ and $\mathrm{C} 5 \mathrm{~b}$, and formation of a membrane attack complex (MAC) [31-34]. These cascades are initiated through three pathways: Classical pathway (CP), Alternative pathway (AP) and Lectin Pathway (LP) with all three pathways merging through a common intersection complement C3 [31-34]. Alternative and classical complement cascades produce different $\mathrm{C} 3$ and $\mathrm{C} 5$ convertases, but both produce the split product of $\mathrm{C} 3$ and $\mathrm{C} 5$ and both form MAC as shown in Fig. 1.

The potential site of complement's therapeutic inhibition

The site of complement activation will determine the type of inhibitor to be used, its route of application and site of 


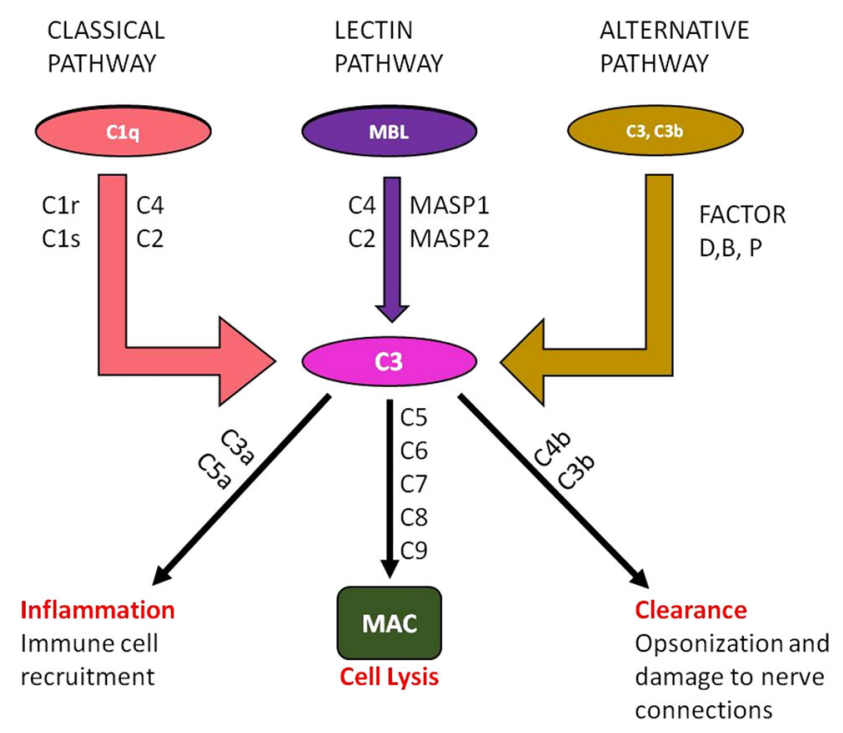

Fig. 1 The complement cascade leading to formation of mark attack complex (MAC) and other alternate effects of complement activation (inflammation and clearance)

inhibition [38]. Many of the procedures are based on the blocking of complement activation at the $\mathrm{C} 3$ level which implies a general and broad inhibition but others are based on the selective blocking of $\mathrm{C} 5$ activation which leads to the inhibition of C5a and C5b-9 formation [38]. Since complement activation is detrimental with deadly consequences, its inhibition should be or can be extended as wide and completely covering all complement factors; however, terminal blockage of the pathway allows C3 activation to offer effective defence mechanism for the body [51, 52]. Clinical validation of the above arguments is limited due to the fact that these arguments are oversimplified because complement activation mechanism and its contribution to pathophysiology of different clinical conditions are very diverse requiring differential approximation and several strategies pertaining to the inhibition process [53]. One such strategy is targeting the initiation step of the complement activation and blocking each of the 3 initial pathways separately [54]. The alternative pathway activation can be inhibited by the inhibition of factor $\mathrm{D}$ (the rate limiting step of the alternative pathway) [54].

Even though blocking AP as an initial step blocks amplification of complement activation, $\mathrm{CP}$ and LP activation remains intact as $\mathrm{C} 1 \mathrm{q}$ or MBL mediated opsonisation and receptor binding are not affected [54]. Also, AP amplification loop may cause detrimental activation no matter the initial trigger [54]. A second strategy involves targeting specific activation products or their respective receptors especially the anaphylatoxins (C3a or C5a) [55]. In certain conditions such as airway hyper-responsiveness, there may be the need or indication of selective blocking of $\mathrm{C} 3 \mathrm{a}$ using anti-C3a antibodies or $\mathrm{C} 3 \mathrm{aR}$ antagonists, which preserves other important $\mathrm{C} 3$ functions [56-58]. In the same way C5a function can be blocked in a condition associated with systemic complement activation, leaving C5b-9 pathway free for pathogenic defence [56-58].

\section{Side effects}

A complete and long-term inhibition of complement may have some detrimental side effects, as suggested by observations made in patients with various complement deficiencies. Such patients have an increased susceptibility to infection (mainly encapsulated bacteria including meningococci and Neisseria), autoimmune and immune complex diseases that arise from impaired opsonisation, adaptive immune response, tolerance or elimination of immune complex [59]. However, in many human diseases only short-term inhibition would be needed, e.g., in ischaemia reperfusion injury or in acute humoral rejection in transplantation [60].

It is important to take a look at the level of complement inhibition especially when considering long-term treatment in chronic diseases as detrimental effects could be reduced by a certain degree of inhibition and still leave defence mechanisms intact [54]. For example, blocking C3 activity leads to a higher risk of infection whilst the selectively blocking of one of the three activation pathways may reduce risk of infection [54, 57]. In addition, it is quite possible that down-regulation rather than blockade of complement may be sufficient on many occasions [61]. Thus, although we should be cautious with inhibiting complement, it would be unwise not to start clinical investigations because of potential side effects which may be prevented (e.g., immunization against meningococcal) or for which a close surveillance can be proposed.

\section{Therapeutic strategies}

\section{Mode of administration, clearance and long-term treatment}

The dosage level and mode of administration of any complement inhibitor depend on the nature of the inhibitor, the nature of the condition to be treated, and the history of the individual patient [38, 62]. Patients suffering from chronic diseases and requiring long-term treatment must have a proper route of administration where it is supposed that oral, nasal or rectal administration are better than intravenous injection [38, 62]. Local application is recommended for organ-specific diseases such as glomerulonephritis [38]. Systemic administration of inhibitors which may be by injection or by transmucosal or transdermal delivery is generally required for systemic diseases 
such as sepsis [38]. Administration by injection may be intravenous, intramuscular, intraperitoneal or subcutaneous [63]. Inhibitors such as recombinant proteins and small molecular inhibitors that have short half-life are best used for the treatment of acute conditions [38]. On the other hand, when they are combined with human immunoglobulins, they acquire increased half-lives [38, 62].

The inhibitors are sometimes made into pharmaceutical compositions (formulations) comprising the inhibitor and a pharmaceutically acceptable carrier [38]. Formulations for injection are generally biocompatible solutions of the active ingredient, such as Hank's solution or saline [38, 63]. Formulations for transdermal or transmucosal administration generally include penetrants such as fusidic acid or bile salts in combination with detergents or surfaceactive agents [64]. The formulations can then be manufactured as aerosols, suppositories or patches which give the inhibitors a longer half-life and subsequently longer clearance [4, 65]. Autoimmune diseases are often chronic, requiring lifelong care and monitoring, even when the person may look or feel well [8, 10]. Currently, few autoimmune diseases can be cured or made to "disappear" with treatment [9]. However, many people with these diseases can live normal lives when they receive appropriate medical care in a long-term treatment [11].

\section{Targeted application}

The main aim of targeted application of complement inhibitors is to reduce any potential side effects whilst trying to treat a condition [66]. This is the best way of treatment if the disease process is clearly organ specific [57]. There can be specific and non-specific targeting where inhibitors are directed at certain organs or cells in the case of specific and any membrane in the case of nonspecific [67]. In non-specific targeting, an approach such as membrane "tagging" is employed. Membrane tagging is achieved by coupling an inhibitor to a lipid tail and this tail binds to the affected membranes [25, 68]. In situations where tagged forms of inhibitors have been used in experiments, they have proved more potent as compared to the parent molecules, highlighting the importance of this approach. sCR1, sCD59 and the rodent complement C3inhibitor Crry have all been tagged with promising results in experiments [4, 67, 68].

Targeted applications have also been achieved by the use of antigen-specificity of antibody-conjugates [68]. In this approach, DAF and IgG antibody were successfully conjugated and targeted to the specific antigen whose antibodies were used. Antigen-targeted forms of sCD59 and CR2 have been produced which bound to C3 opsonised cells and showed a higher or greater potency than when the conjugates were used individually [67]. Another targeting approach is the conjugation of the inhibitor to an inflammation modulating molecule $[67,68]$. One such conjugate is sCR1-sL(x) which combines complement inhibition with leukocyte recruitment and adhesion as the $\mathrm{sL}(\mathrm{x})$ is a ligand for $\mathrm{E}$ and $\mathrm{P}$ selectins which facilitates the leukocyte adhesion [69]. This combination was found to be highly potent in comparison with the sCR1 by itself [69].

\section{Gene therapy}

This is where a "normal"' gene is inserted into the genome to replace an "abnormal" disease causing gene. A carrier molecule called a vector must be used to deliver the therapeutic gene to the patient's target cells [70]. Currently, the most common vector is a virus that has been genetically altered to carry normal human DNA [70, 71]. A gene therapy approach using retrovirally transduced soluble complement receptor 1 (CD35), an inhibitor of the classical and alternative pathway of complement activation in DBA/ 1 mice, has been shown to have a beneficial effect, reducing inflammation and the development of collageninduced arthritis (CIA) in these mice [71].

\section{Complement inhibitors}

The proteins which inhibit complement activation in fluid phase limit the generation of complement fragments such as $\mathrm{C} 4 \mathrm{~b}$ and $\mathrm{C} 3 \mathrm{~b}$ [72]. They also render these fragments inactive thereby reducing the extent of cellular damage to self cells. These fluid phase proteins include $\mathrm{C} 1$-inhibitor (C1-INH), C4-binding protein (C4BP), factor $\mathrm{H}$, and factor I [72]. In addition, two fluid phase proteins, clusterin and vitronectin inhibit the formation of cytolytic MAC [51]. These inhibitors are regulators of the complement system and keep the system under control by inhibiting its activation except properdin that stabilises alternative $\mathrm{C} 3$ convertase [51, 72].

$\mathrm{C} 4 \mathrm{~b}$ and $\mathrm{C} 3 \mathrm{~b}$ fragments may escape inactivation by fluid phase inhibitors of complement activation and can get fixed to self cells [73]. These fragments are inactivated by cell membrane embedded regulators of complement such as DAF, MCP and CR1 [72, 73]. If the activation of complement is extensive, in spite of the action of DAF, MCP and CR1, a significant extent of C3/C5 convertases may be formed on self cell which can sequentially generate MAC which could cause cell lysis [72, 73].

Two cell membrane proteins, CD59 and homologous restriction factor (HRF), render MAC non-cytolytic while it is being formed on the self cell [74]. Non-cytolytic MAC can activate self cell but cannot lyse it [74]. Thus, cell surface regulators of formation of $\mathrm{C} 3 / \mathrm{C} 5$-convertases and MAC protect self cell from lysis [68]. Fluid phase 
inhibitors in conjunction with membrane embedded inhibitors protect cells from autologous complement [68]. It is important to note that most of the drugs that qualifies as candidates for therapeutic complement inhibition are either naturally occurring complement inhibitory proteins or their derivatives $[68,74]$.

\section{C1-inihibitor}

C1-inhibitor (CI-INH) is a serine protease inhibitor protein (serpin) that is naturally occurring [72]. It is the largest member of the serpin class of proteins (G1) and probably the highest glycosylated [72]. It has an O-glycosylated residue which is uncommon for proteins that are not membrane-bound and inhibits $\mathrm{Clr}$ and $\mathrm{C} 1 \mathrm{~s}$ as well as controlling mannose-binding protein-associated serine protease (MASP)-1 and MASP-2 of the lectin pathway [75].

The gene for human C1-inhibitor is located on the eleventh chromosome (11q11-q13.1) and is produced mainly in the liver, but also by activated monocytes and other cell types [72]. It circulates in blood at levels of around $0.25-0.45 \mathrm{~g} / \mathrm{l}$ and is the major inhibitor of both the early activation steps of classical pathway and contact activation of the complement system [51, 54]. Deficiency of this protein is associated with hereditary angioedema which is the swelling of the blood vessels [76].

Patients of hereditary angioedema have defects in one of the two genes responsible for formation of CI-INH [76]. These patients have one half to one-third the normal level of CI-INH and have frequent attacks of angioedema which may arise from activation of the kinin generating system or from activation of the complement system with generation of peptides that cause vascular leakage [76].

\section{Advantages}

C1-esterase inhibitor (C1-INH) concentrate prepared from human plasma is being successfully used for the treatment of hereditary angioneurotic oedema. Recently, C1-INH has been found to be consumed in severe inflammation and has been shown to exert beneficial effects in several inflammatory conditions such as human sepsis, postoperative myocardial dysfunction due to reperfusion injury, severe capillary leakage syndrome after bone marrow transplantation, reperfusion injury after lung transplantation, burn, and cytotoxicity caused by IL-2 therapy in cancer $[51,76]$.

C1-INH also regulates the activation of kallikrein, plasmin in the fibrinolytic pathway, the activation of factor $\mathrm{XI}$ in the coagulation cascade and activated factor XIIa [77]. In the presence of C1-INH deficiency, the classical complement pathway can be inappropriately or excessively activated [78]. Immune complexes trigger the activation of the first component $\mathrm{C} 1$ to $\mathrm{C} 1$ esterase and $\mathrm{C} 1$ esterase then acts with its natural substrates $\mathrm{C} 4$ and $\mathrm{C} 2$ to form the complex C4b2b [77]. Formation of this new complex (and associated $\mathrm{C} 3$ activation) leads to the production of anaphylactic, chemotactic and vasoactive peptides (C2a, C3a, C5a) [78].

C1-INH protein blocks both the spontaneous activation of $\mathrm{C} 1$ and the formation of activated $\mathrm{C} 1$, therefore not allowing the $\mathrm{C} 2,4$ complex to be created $[71,72]$. In the kinin releasing system, $\mathrm{C} 1 \mathrm{INH}$ regulates conversion of prekallikrein to kallikrein [72]. C1-INH deficiency results in an increase in kallikrein, which in turn increases bradykinin production [77]. Long-term prophylaxis with C1INH may be necessary in patients where tranexamic acid or steroids are not effective, not tolerated or contraindicated [71]. This may include those with underlying thromboembolic disease or during pregnancy $[75,77]$.

\section{Disadvantages}

C1-inhibitor has been widely used in a number of clinical conditions and when used for therapeutic treatment, it is not necessary complement dependent, but may well be explained by inhibition of other proteins [79]. C1-inhibitor deficiency is the bases on which treatment is offered as controlled studies are not available [79]. Inhibitory effects of C1-INH on factor XIIa, factor XIa and plasmin have also been described with the end result of increased vascular permeability and massive local uncontrolled oedema [77, 79]. This implies that CI-INH is not only complement related but other substances as well [72].

\section{Recombinant proteins}

These include the use of pharmacological agents such as soluble recombinant human CR1, CR2, MCP, DAF, C4BP and factor $\mathrm{H}[80]$. All the complement regulatory proteins are candidates when extensive inhibition of complement is required $[49,50]$. This is because they all interfere with the activity of C3 and C5 convertases except CR2 which may play a minor role $[49,50]$.

Compared with conventional drugs, recombinant proteins for therapy remain attractive to date, for reasons having to do with both the biological properties of proteins and the economics of drug development [81]. The time required to develop protein drugs is shorter than that for conventional drugs and, although a therapeutic protein has a $40 \%$ probability of becoming a marketable drug, this figure is approximately $10 \%$ for a new chemical entity, partly because of the lower toxicity of proteins compared with chemical compounds $[4,81]$. The use of recombinant proteins, however, has its advantages as well as disadvantages [4]. 


\section{Soluble CR1}

Several recombinant variants of complement receptor 1 (CR1) have been produced with the most effective of these appearing to be sCR1-SLe x [68]. The sCR1 part of this recombinant inhibits complement and the carbohydrate SLe $x$ moiety inhibits selectin mediated interactions of neutrophils and lymphocytes with endothelium [68]. Although clinical trials of sCR1 in humans are eagerly awaited, several of the recombinant versions of sCR1 have been shown to suppress ischaemia reperfusion injury, thermal trauma and immune complex mediated inflammation [68].

Advantages of soluble CRI CR1 has cofactor and decay accelerating activity in both classical and alternate pathways [67]. Deletion of the transmembrane part of the molecule leads to the production of the soluble form-sCR1 which is potent in their inhibitory activity at concentrations equivalent to $1 \%$ of physiological C4BP and factor $\mathrm{H}$ [67]. When combined with an albumin binding receptor, sCR1 attains a longer half-life with improved targeting [67].

There has been a lot of use of sCR1 in a number of animal disease models that has given a lot of promising results with prevention in the following conditions; liver injury, local and remote lung injury in skeletal muscle, local and remote injury in rat intestine and gut ischaemia and endothelial cell function after haemorrhage and resuscitation in rats [82]. sCR1 has been shown to prevent tissue damage in experimental myocardial infarction [82].

A lot more benefits of sCR1 have been recorded with regard to autoimmune diseases including, immune-complex and complement-mediated lung injuries and thermal trauma in rats, passive reverse Arthus reaction and dermal immune complex mediated vasculitis in experimental arthritis in rats [53]. In experimental glomerulonephritis, myasthenia gravis as well as allergic encephalomyelitis, sCR1 has proved to be efficient in treatment [52].

sCR1 has been shown experimentally to be effective in reducing hyperacute rejection in xenotransplantation highlighting the role of complement in graft rejection [83]. Even in allotransplant, sCR1 showed beneficial effects. With development of sCR1 into a pharmaceutical preparation which has been tested in patients with acute myocardial infarction, lung transplantation and post-cardiopulmonary bypass syndrome, results of efficient complement inhibition have been shown [70]. In patients with factor $\mathrm{H}$ deficiency, soluble recombinant $\mathrm{CR} 1$ may block immediately the excessive activation of complement and restore C3 levels [84].

Disadvantages of soluble CRI On its own, $\mathrm{SCR} 1$ has a short half-life and only acquires a longer and sustainable half-life when it is recombined with other substances [83]. It lacks a proper targeting on its own and if not properly administered, will not give a good end result [83].

\section{$C 4 B P$, factor $H$ and factor $I$}

$\mathrm{C} 4 \mathrm{BP}$ and factor I are responsible for regulation of $\mathrm{C} 4 \mathrm{~b}$. $\mathrm{C} 4 \mathrm{BP}$ binds to $\mathrm{C} 4 \mathrm{~b}$ and facilitates its cleavage by the proteolytic enzyme factor I [85]. Factor $\mathrm{H}$ acts as an obligate cofactor in the fluid phase and as an accelerator of C3 cleavage on cell surfaces [84, 85].

Advantages of $C 4 B P$, factor $H$ and factor $I$ Factor $\mathrm{H}$, Factor I and C4-binding protein (C4BP) are soluble complement inhibitors that are likely to be effective membranes in complement-mediated diseases if they inhibit activation of complement before or at the stage of formation of $\mathrm{C} 3 / \mathrm{C} 5$ convertase [71]. C4BP has been shown to inhibit the classical pathway whilst Factor $\mathrm{H}$ inhibits the alternate pathway [85]. This inhibition suppresses damage of self cells and C5a-induced recruitment of neutrophils and inflammation.

Besides the potential uses of fluid phase regulators in substitution therapy, a novel use of C4BP came into light when it was shown that human complement on swine endothelial cells was inhibited by a surface bound form of C4BP-GPI (consisting of short consensus repeats 1-8 (SCRs1-8) of a-chain of C4BP and a glycosyl-phosphatidyl-inositol (GPI) moiety of DAF [86]. Surface-induced complement activation was abrogated by the binding of Factor $\mathrm{H}$ to artificial surface which also improved biocompatibility [67].

Several patients who suffer from factor I deficiency have been diagnosed [87]. In this deficiency, regulation of C3/ C5-convertase of the alternative pathway is impaired [87, 88]. These patients have very low plasma levels of native C3 and factor B [87]. The underlying basis for this low plasma level of $\mathrm{C} 3$ and factor $\mathrm{B}$ seems to be the increased generation of $\mathrm{C} 3 \mathrm{bBb}$ complex whose decay is reduced due to factor I deficiency [88]. Circulating $\mathrm{C} 3 \mathrm{bBb}$ generates high levels of $\mathrm{C} 3 \mathrm{~b}$ which in turn leads to the generation of more $\mathrm{C} 3 \mathrm{bBb}$ complex $[87,88]$. Free $\mathrm{C} 3 \mathrm{~b}$ or $\mathrm{C} 3 \mathrm{~b}$ in this complex is not converted to $\mathrm{C} 3 \mathrm{bi}$ or $\mathrm{C} 3 \mathrm{~d}$. Administration of factor I to one of the patients with factor I deficiency normalized C3b levels within few minutes [87, 88]. Factor I, Factor $\mathrm{H}$ and C4BP are likely to be effective in substitution therapy in patients with their deficiencies [87, 88]. Factor I has been used in the treatment of factor I deficiency $[87,88]$.

Disadvantages of C4BP, factor $\mathrm{H}$ and factor $\mathrm{I}$ Factor $\mathrm{H}$ and $\mathrm{C} 4 \mathrm{BP}$ are far much less potent than recombinant soluble CR1 in inhibiting classical and alternative pathways 
[75]. Thus, they have not been used in the treatment of complement-mediated diseases. Although recombinant factor $\mathrm{H}$ has been produced, neither natural nor recombinant factor $\mathrm{H}$ has been tried in factor $\mathrm{H}$ deficiency. C4BP has also not yet been tried in the replacement therapy in C4BP deficiency [84, 85].

\section{Soluble DAF}

Decay accelerating factor (DAF) (CD55) is a single-chain membrane protein that is a potent accelerator of $\mathrm{C} 3$ and $\mathrm{C} 5$ convertase decay [89]. It has no factor I cofactor activity and acts to limit membrane damage if complement is activated on a host cell surface [89].

Advantages of soluble DAF DAF is composed of four short consensus repeats (SCRs) plus a serine/threonineenriched domain that is capable of extensive O-linked glycosylation [90]. DAF is attached to cell membranes by a GPI anchor and through its ability to bind $\mathrm{C} 4 \mathrm{~b}$ and $\mathrm{C} 3 \mathrm{~b}$; it acts by dissociating the $\mathrm{C} 3$ and $\mathrm{C} 5$ convertases in both the classical and alternative pathways [90]. Soluble versions of DAF (sDAF) have been shown to inhibit complement activation in vitro as well as in the reversed passive Arthus reaction in guinea pigs [53].

Disadvantages of soluble DAF Unlike CR1, which possesses both extrinsic and intrinsic activity, DAF functions only intrinsically by inactivating convertases assembled on the same cell membrane on which it is expressed and not those convertases formed on external membranes [90].

\section{Soluble MCP}

With Membrane cofactor protein (MCP), a limited number of studies have so far been carried out with regard to recombinant sMCP's ability to inhibit complement in vitro and in vivo and with organs of animals transgenic for hMCP in the field of xenotransplantation [70].

Advantages of soluble MCP $\mathrm{sMCP}$ has been shown to prevent reverse passive Arthus reaction and prolonged hyperacute xenograft rejection. Also, sMCP fused with a soluble form of the low affinity human IgG receptor $\mathrm{Fc}$ gamma RII proved to be more effective in protecting xenograft rejection than SMCP on its own [64].

A combination of SDAF and SMCP that retains decay acceleration and cofactor activity is more potent than each protein on its own. This recombinant Chlorophyll a-b binding protein 2 (CAB-2) has been able to offer protection in the passive reverse Arthus reaction and in Forssman shock [91].
Disadvantages of soluble MCP There has been limited number of studies carried out regarding soluble MCP and therefore its ability as therapy cannot be emphasised [38]. Soluble MCP is not as potent on its own as when it is combined with other substances [38].

\section{Soluble CD59}

Advantages of soluble CD59 CD59 is yet another regulatory protein that prevents assembly of the complete C5b9 complex on target cells and so prevents complementmediated lysis. In certain forms of glomerulonephritis, arthritis and encephalomyelitis selective C5b-9 may be indicated which will require the use of CD59 [68].

Disadvantages of soluble CD59 A soluble form of CD59 which is inefficient in the fluid phase has been constructed. It is being fused with sDAF with the hope of creating a recombinant that has a C5b-9 and C3/C5 inhibitory activity but its therapeutic effect has not been shown [92].

\section{Using antibodies}

It has been reported that intravenous immunoglobulin blocks the binding of C3 to target tissues [38]. Subsequently, it was reported that not only is $\mathrm{C} 3$ binding to target tissues blocked by high levels of monomeric immunoglobulin, but $\mathrm{C} 4$ binding to target tissues is blocked as well [38]. There are data that suggest that since $\mathrm{C} 4$ must be activated and must bind to a target before $\mathrm{C} 3$, it is the blocking of $\mathrm{C} 4$ binding that is central to classical pathway inhibition [55]. Further research has now shown that this blockade is due to activity of the Fc fragment of the IgG [55]. There is the combined advantage of specificity and long half-life with the use of monoclonal antibodies, the only problem being the mode of administration which is parenteral.

\section{Anti-MBL, anti-factor $D$ and anti-properdin}

The lectin pathway is the third pathway through which complement is activated and is shown to have importance in pathogenesis of ischaemia-reperfusion injury [31]. An anti-MBL antibody against the lectin pathway has been developed and has been shown experimentally to improve survival in septicaemia [75].

Anti-factor D against factor D, the rate limiting step in the alternative pathway has been developed and has been tested in baboons undergoing Cardiopulmonary bypass (CPB) where they were found to inhibit complement and leukocyte activation [93]. Properdin binds to C3 convertase $(\mathrm{C} 3 \mathrm{bBb})$ and stabilises it, thus slowing its decay and 
allowing it to continue the complement cascade. Antiproperdin therefore prevents the continuation of the complement cascade [93].

\section{Anti-C5}

Inhibition of C5 activation using high-affinity anti-C5 monoclonal antibodies presents another therapeutic approach for blocking complement activation [88]. This strategy is aimed at inhibiting the formation of C5a and C5b-9 via both the classical and alternative pathways, without affecting the generation of $\mathrm{C} 3 \mathrm{~b}$, a $\mathrm{C} 3$ opsonic product that is critical for antibacterial defences [88].

Another suggested advantage of using monoclonal antibodies to block $\mathrm{C} 5$ activation is the prevention of the direct cleavage and activation of $\mathrm{C} 5$ by oxygen radicals or by enzymes released from injured tissues during inflammation [89]. There are no natural inhibitors for activated $\mathrm{C} 5$ and they can be activated independent of $\mathrm{C} 3$, bringing forth the need to develop specific inhibitors.

Anti-C5 antibody has been used experimentally to treat collagen-induced arthritis which prevented the disease from the onset and also treated existing disease [88]. In experimental myocardial infarction, anti-rat C5 monoclonal antibody was found to be protective, also in an artificial cardiopulmonary bypass model, there was demonstration of terminal pathway activation inhibition [94]. Hyperacute graft rejection in a model was also prevented [94].

Some anti-C5 antibodies such as the humanized single fragment (h5D1.1-scFv) have actually reached clinical trials called pexelizumab with a focus on targeting complement in cardiovascular disease. Pexelizumab trials have shown a lot of benefits including complement inhibition with subsequent reduced leukocyte activation and postoperative complications in patients undergoing $\mathrm{CPB}$; patients with isolated coronary artery bypass grafting; and reduction in death and myocardial infarction [94]. C-reactive protein (CRP) and IL-6, which are both mediators correlating to mortality, were shown to be significantly reduced in patients treated with Pexelizumab.

\section{Anti-C5a}

As the most biologically potent fragment formed from C5 during complement activation, C5a is a good target for inhibition when looking to prevent complement activation. There has recently been an approach using monoclonal antibodies that react with $\mathrm{C} 5 \mathrm{a}$ without inhibiting the cleavage of C5 [95]. In this approach, C5a is pre-neutralized before its formation and thereby have the efficacy of C5a neutralization increased. This has been investigated with human whole blood of Neisseria infection where there was complete inhibition of inflammatory reaction with no effect on bacterial killing.

Anti-C5a antibodies have been shown to reduce myocardial injury, reduced neutrophil-mediated impairment of endothelium-dependent relaxation after CPB, reduced local and remote injury in intestinal injury, improved survival and reduced Il-6 production and oxygen demand [94]. A possible role of C5a in activation of other plasma cascade system was shown in a rat model when C5a antibodies ameliorated impairment of the coagulation and fibrinolytic system.

\section{Anti-C5b-9}

Prevention of formation of C5b-9 has been found to reduce tissue damage in rat hearts perfused with human serum. This was achieved with the use of anti-C8 which also inhibited platelet activation during simulated CPB [89].

\section{Small molecule inhibitors}

Small molecule peptides and their derivatives are useful in therapeutic and prophylactic contexts [96]. As complement binding can account for substantial tissue damage in a wide variety of autoimmune/immune complex mediated syndromes such as systemic lupus erythematosus and vasculitis, inhibition of the complement system by peptides is likely to be desirable therapeutic intervention in these cases [55]. Peptides can also be used to inhibit complement activation, which is desirable in cases that involve tissue damage brought about by vascular injury such as myocardial infarction, cerebral vascular accidents or acute shock lung syndrome [96].

\section{C1 binding peptides}

Peptide fragments of the Fc fragment of IgG that retain the complement blocking activity of intact immunoglobulin, as well as derivatives of such peptides that interact with $\mathrm{Clq}$ have been produced [51]. They prolong xenograft survival and it should be noted that $\mathrm{C} 1 \mathrm{q}$ is activated by several substances which may be of pathogenic importance but only by antibodies [52].

\section{Compstatin}

Compstatin is a 13-residue cyclic peptide that was isolated with the use of combinatorial peptide libraries to identify $\mathrm{C} 3$ binding peptides. Compstatin blocks cleavage of $\mathrm{C} 3$ and highly specific for C3 binding [97]. In an in vitro model of extra corporal circulation, compstatin was found to reduce complement and granulocyte activation. Animal studies of this peptide are limited because it works only in primates. 
There have been a number of natural and synthetic substances that have come out as having complement inhibitory capability but may not be complement specific [4]. They have a number of effects on complement and several complement inhibitory proteins including C1-inhibitor [4]. Some of these substances include: high-dose intravenous immunoglobulins (IVIG), Cobra venom factor (CVF), nafamostat mesilate, aprotinin, K-76 monocarboxylic acid and heparin [38].

\section{Eculizumab}

Eculizumab which is formulated to soliris is a humanized monoclonal antibody against complement protein C5 that inhibits terminal complement activation [5]. It has been shown to prevent complications of some autoimmune diseases and improve quality of life and overall survival [98]. As stated, eculizumab is a recombinant humanized monoclonal $\operatorname{IgG} 2 / 4 \kappa$ antibody produced by murine myeloma cell culture and purified by standard bioprocess technology. It contains human constant regions from human IgG2 sequences and human IgG4 sequences and murine complementarity-determining regions grafted onto the human framework light- and heavy-chain variable regions. Again, eculizumab is composed of two 448 amino acid heavy chains and two 214 amino acid light chains and has a molecular weight of approximately $148 \mathrm{kDa}$ [99]. It is made into a sterile, clear, colourless, preservative-free $10 \mathrm{mg} / \mathrm{mL}$ solution for intravenous infusion and is supplied in 30-mL single-use vials. It is formulated at $\mathrm{pH} 7$ and each vial contains $300 \mathrm{mg}$ of eculizumab, $13.8 \mathrm{mg}$ sodium phosphate monobasic, $53.4 \mathrm{mg}$ sodium phosphate dibasic, $263.1 \mathrm{mg}$ sodium chloride, $6.6 \mathrm{mg}$ polysorbate 80 (vegetable origin) and Water for Injection [100].

Eculizumab selectively targets and inhibits the terminal portion of the complement cascade. It specifically binds to the terminal Complement component 5, or $\mathrm{C} 5$, which acts at a late stage in the complement cascade [2, 48]. When activated, C5 is involved in activating host cells, thereby attracting pro-inflammatory immune cells, while also destroying cells by triggering pore formation [2]. By inhibiting the complement cascade at this point, the normal, disease-preventing functions of proximal complement system are largely preserved, while the properties of C5 that promote inflammation and cell destruction are impeded [101]. Eculizumab therefore inhibits the cleavage of $\mathrm{C} 5$ to $\mathrm{C} 5 \mathrm{a}$ and $\mathrm{C} 5 \mathrm{~b}$ by the $\mathrm{C} 5$ convertase, which prevents the generation of the terminal complement complex C5b-9. Both C5a and C5b-9 cause the terminal complement-mediated events that are characteristic of paroxysmal nocturnal hemoglobinuria (PNH) and atypical haemolytic uraemic syndrome (aHUS) [101]. Eculizumab injection is therefore used to treat PNH and aHUS [99, 102].
The metabolism of eculizumab is thought to occur via lysosomal enzymes that cleave the antibody to generate small peptides and amino acids and the volume of distribution of eculizumab in humans approximates that of plasma [99].

\section{Discussion}

Activation of complement is an essential part of the mechanism of pathogenesis of a large number of human diseases [2]. Inhibition of complement activation by pharmacological means is therefore likely to suppress or prevent disease processes in complement-mediated diseases [3]. It is for this reason that low molecular weight synthetic inhibitors of complement are being developed and high molecular weight natural inhibitors of human origin present in plasma or embedded in cell membrane are also being purified or produced in their recombinant forms [49].

To develop effective and safe anti-complement therapeutics, however, the main issue or challenge is to balance the beneficial effects that are obtained by the inhibition with the preservation of sufficient functional activity for antimicrobial protection and for tissue homoeostasis as complement has other beneficial effects in combating infection [30, 49]. There is much enthusiasm for such therapies that will probably be disease specific so as to prevent any possible associated side effects. Studies have been performed and some are still ongoing in both rodents and humans using different inhibitors and testing administration routes ito come out with the right therapy [38].

Most of the evidence for the role of complement in preventing systemic damage comes from experimental data obtained in these studies in which the addition of complement inhibitors blocks or reduces damage [49]. As said, specific inhibitors of complement might produce beneficial effects, but also the possible caveats related to the inhibition of enzymatic cascade that is central to the normal function of the immune system which a proper or ideal therapy must seek to prevent [66]. The emergence of structure-based drug design for the development of small synthetic molecules for therapy holds promise, in spite of formidable technical challenges.

Even though a lot of research has gone into finding the use of complement in combating diseases, there is still the need for more experimental exercises or studies to provide more understanding into the mechanisms of complement mediated damages. When a good insight is gained as to how complement causes diseases, it will help provide a good approach in designing the appropriate treatment that will have a specific target to provide the needed cure. Also identification of the component needed to be tackled or 
inhibited in a specific condition and targeting the actual site to be inhibited in inflammation will be ideal to offer proper treatment and avoid any side effects.

In contrast to inhibitors of the coagulation cascade, the clinical application of complement inhibitors is still in its infancy as robust data demonstrating clinical benefits are still being produced. This might explain why so little attention has been given by clinicians to this field. For the time being, the good news is that some complement inhibitors have already reached clinical phase I and II studies as medical science strives to reach its goal in designing therapies that target various steps in the immune response $[6,25]$. Table 1 shows some of the latest clinical studies of complement inhibitors in human.

Current therapies of autoimmune diseases focus on trying to alleviate symptoms, but fail to correct the fundamental immune defects that lead to the pathology highlighting the reason why the clinical management of autoimmune diseases has been such a difficult task [24]. To this end, new approaches such as therapeutic agents that inhibit complement activation and prevent autoimmune disease must receive the greatest attention [25]. It is our opinion that when the best of the inhibitors being looked at is well purified and passed through all the clinical trials to show the highest capability of blocking complement components from initiating the activation cascade, such an inhibitor may be of a great benefit in the prevention and treatment of autoimmune diseases.

Complement is believed to play a major role in host defence against infection, but can cause damage to the host system as well [1]. It is this damage that leads to it playing a role in human diseases. In general, complement causes damage by three mechanisms [4]. For certain targets, interaction of the complement proteins with the target cell or microorganism causes direct lysis of that microorganism or cell [82]. In a second series of reactions, complement proteins deposited on cells or microorganisms interact with a series of specific receptors on phagocytes that aid in the phagocytic process, thus removing the pathologic cell or microorganism from the body [82].

Table 1 A table presenting some latest clinical studies of complement inhibitors in human

\begin{tabular}{|c|c|c|}
\hline No. & Clinical study & References \\
\hline 1 & $\begin{array}{l}\text { Adjuvant treatment with dexamethasone plus anti-C5 antibodies improves outcome of experimental pneumococcal } \\
\text { meningitis: a randomized controlled trail }\end{array}$ & [104] \\
\hline 2 & $\begin{array}{l}\text { Atypical haemolytic syndrome treated with the complement inhibitor eculizumab: the experience of the Australian } \\
\text { compassionate access cohort }\end{array}$ & {$[105]$} \\
\hline 3 & Therapeutic drug monitoring of eculizumab: rationale for an individualized dosing schedule & [106] \\
\hline 4 & Complement inhibition for paroxysmal nocturnal hemoglobinuria: where we stand and where we are going & [107] \\
\hline 5 & Inhibition of aberrant complement activation by a dimer of acetylsalicylic acid & [108] \\
\hline 6 & Expanding role of therapeutic antibodies & [109] \\
\hline 7 & A novel anticonvulsant mechanism via inhibition of complement receptor C5ar1 in murine epilepsy models & [110] \\
\hline 8 & Current and future pharmacologic complement inhibitors & [111] \\
\hline 9 & Successful use of eculizumab for treatment of an acute hemolytic reaction after ABO-incompatible red blood cell transfusion & [112] \\
\hline 10 & Compstatin: a C3-targeted complement inhibitor reaching its prime for bedside intervention & [113] \\
\hline 11 & Dissecting complement blockade for clinic use & [114] \\
\hline 12 & Complement therapy in atypical haemolytic uraemic syndrome (aHUS) & [115] \\
\hline 13 & Paroxysmal nocturnal haemoglobinuria and the age of therapeutic complement inhibition & [116] \\
\hline 14 & Complement inhibitors in phase 1 and 2 clinical studies for immunological disorders & [117] \\
\hline 15 & Inhibition of complement activation (eculizumab) in Guillain-Barre syndrome study & [118] \\
\hline 16 & An open label clinical trial of complement inhibition in multifocal motor neuropathy & [119] \\
\hline 17 & $\begin{array}{l}\text { Expression of complement inhibitors CD46, CD55, and CD59 on tumor cells does not predict clinical outcome after } \\
\text { rituximab treatment in follicular non-Hodgkin }\end{array}$ & {$[120]$} \\
\hline 18 & Complement activation and inhibition: a delicate balance & [121] \\
\hline 19 & Complement-mediated ischemia-reperfusion injury: lessons learned from animal and clinical studies & [122] \\
\hline 20 & Compstatin: a complement inhibitor on its way to clinical application & [123] \\
\hline 21 & $\begin{array}{l}\text { Shotgun proteomics implicates protease inhibition and complement activation in the anti-inflammatory properties of high } \\
\text { density lipoprotein (HDL) }\end{array}$ & [124] \\
\hline 22 & $\begin{array}{l}\text { Discovery and development of the complement inhibitor eculizumab for the treatment of paroxysmal nocturnal } \\
\text { hemoglobinuria }\end{array}$ & [5] \\
\hline
\end{tabular}


Complement activation also leads to the generation of a series of activation peptides that are capable of producing inflammation [103]. In addition, complement is thought to play a major role in the afferent limb of the immune response, increasing the immunogenicity of antigens with bound complement peptides [36]. It may also be important in eliminating clones of lymphocytes involved in the immune response to self antigens [64].

One of the diseases associated with complement activation is autoimmune disease [8]. Autoimmune diseases represent a class of diseases which are often difficult to treat effectively [9]. Although there are a number of drugs which exist to treat them, none are adequate to control or inhibit complement activation which is thought to trigger the disease $[10,11]$. The inhibition of complement may be very important in a variety of these diseases because as the complement system becomes active, there may be destruction and removal of cells and substances, which may be detrimental to the individual [32]. It is useful, therefore, to have substances which can be administered to patients to prevent active complement activation.

Many complement inhibitory substances have been considered as therapeutic agents in helping to avert complement-mediated damage leading to autoimmune disease. Among the substances mentioned include CI- inhibitor, recombinant proteins such as soluble CR1, C4BP, Factor H, Factor I, DAF, MCP, CD59, antibodies comprising Anti-MBL, -Factor D, -Properdin, -C5, C5a and C5b-9 and finally small molecule inhibitors such as CI-binding peptide and compstatin [64, 70, 90, 91].

The mode of administration, clearance and long-term treatment, targeted organ or cells and potential side effects of the substances if available have been considered to ensure that qualified ones have been subjected to all kinds of tests during trial and if their efficacy is proven, then they can be used therapeutically for treatment of autoimmune disease targeting complement activation [25, 38].

\section{Conclusion}

In the future as more and new complement inhibitors are being discovered, there is the possibility that a better inhibitor of complement activation will be found which will help provide a formidable treatment for autoimmune disease. Compared with conventional drugs, it is our opinion that the use of complement inhibitors will be the best option for treatment of autoimmune diseases based on the advantages of the inhibitors outlined above.

Acknowledgments We are grateful to Prof. Patrick F. Ayeh-Kumi the Dean of the School of Biomedical and Allied Health Sciences (SBAHS), College of Health Sciences, University of Ghana for his assistance in the development and drafting of the manuscript. We will also like to acknowledge the following persons for their help in putting the manuscript together: Dr. I.A Bello, Dr. Charles Brown and Mr. David Nana Adjei, all of SBAHS.

\section{Compliance with ethical standards}

Conflict of interest Author Samuel Antwi-Baffour, Author Jonathan Adjei, Author Claudia Aryeh and Author Ransford Kyeremeh declare that they have no conflict of interest.

Human and animal rights All procedures performed in studies involving human participants were in accordance with the ethical standards of the institutional and/or national research committee and with the 1964 Helsinki declaration and its later amendments or comparable ethical standards.

Informed consent For this type of study, formal consent is not required.

\section{References}

1. Ballanti E, Perricone C, Greco E, Ballanti M, Di Muzio G, Chimenti MS et al (2013) Complement and autoimmunity. Immunol Res 56(2-3):477-491

2. Hietala MA, Nandakumar KS, Persson L, Fahlen S, Holmdahl R, Pekna M (2004) Complement activation by both classical and alternative pathways is critical for the effector phase of arthritis. Eur J Immunol 34:1208-1216

3. Lappegård KT, Bjerre A, Tjønnfjord GE, Mollnes TE (2015) Therapeutic complement inhibition-from experimental to clinical medicine. Tidsskr Nor Laegeforen 135:1745-1749

4. Hori Y, Yamada K, Hanafusa N, Okuda T, Okada N, Miyata T et al (1999) Crry, a complement regulatory protein, modulates renal interstitial disease induced by proteinuria. Kidney Int 56:2096-2106

5. Rother RP, Rollins SA, Mojcik CF, Brodsky RA, Bell L (2007) Discovery and development of the complement inhibitor eculizumab for the treatment of paroxysmal nocturnal hemoglobinuria. Nat Biotechnol 25(11):1256-1264

6. Klos A, Wende E, Wareham KJ, Monk PN (2013) International union of pharmacology. Complement peptide $\mathrm{C} 5 \mathrm{a}, \mathrm{C} 4 \mathrm{a}$, and $\mathrm{C} 3 \mathrm{a}$ receptors. Pharmacol Rev 65(1):500-543

7. Ratner M (2006) Complement inhibitors finally find orphan niches. Nat Biotechnol 24:371-372

8. Rose NR, Mackay IR (2014) The autoimmune diseases, Chap. 70, 5th edn. Elsevier/Academic Press, Amsterdam

9. Seroogy CM, Fathman CG (2000) The application of gene therapy in autoimmune diseases. Gene Ther 7(1):9-13

10. Romagnani S (2006) Immunological tolerance and autoimmunity. Intern Emerg Med 1(3):187-196

11. Choi J, Kim ST, Craft J (2012) The pathogenesis of systemic lupus erythematosus-an update. Curr Opin Immunol 24(6):651-657

12. Perniola R (2012) Expression of the autoimmune regulator gene and its relevance to the mechanisms of central and peripheral tolerance. Clin Dev Immunol 2012:1-12

13. Poletaev AB, Churilov LP, Stroev YI, Agapov MM (2012) Immunophysiology versus immunopathology: natural autoimmunity in human health and disease. Pathophysiology 19(3):221-231

14. Edwards JC, Cambridge G (2006) B-cell targeting in rheumatoid arthritis and other autoimmune diseases. Nat Rev Immunol 6(5):394-403 
15. Edwards JC, Cambridge G, Abrahams VM (1999) Do self perpetuating B lymphocytes drive human autoimmune disease? Immunol 99:188-196

16. Grammatikos A, Tsokos G (2012) Immunodeficiency and autoimmunity: lessons from systemic lupus erythematosus. Trends Mol Med 18(2):101-108

17. Klein J, Sato A (2000) The HLA system. Second of two parts. N Engl J Med 343(11):782-786

18. Everyday Health-Women and Autoimmune Disorders By McCoy K. Medically reviewed by Marcellin L. Last Updated: 12/02/2009. http://www.everydayhealth.com/. Accessed on 20 Oct 2016

19. Vandebriel RJ, De Jong HJ, Gremmer ER, Klungel OH, Tervaert JW, Slob W et al (2012) Statins accelerate the onset of collagen type II-induced arthritis in mice. Arthritis Res Ther 14(2):R90

20. Compston A, Coles A (2008) Multiple sclerosis. Lancet 372(9648):1502-1517

21. Baumgart DC, Sandborn WJ (2012) Crohn's disease. Lancet 380(9853):1590-1605

22. Cooke DW, Plotnick L (2008) Type 1 diabetes mellitus in pediatrics. Pediatr Rev 29(11):374-384

23. Rosman Z, Shoenfeld Y, Zandman-Goddard G (2013) Biologic therapy for autoimmune diseases: an update. BMC Med 11:88

24. Sykes M, Nikolic B (2005) Treatment of severe autoimmune disease by stem-cell transplantation. Nature 435:620-627

25. Mollnes TE, Kirschfink M (2006) Strategies of therapeutic complement inhibition. Mol Immunol 43(1-2):107-121

26. Janeway CA Jr, Travers P, Walport M, Shlomchik MJ (2001) The complement system and innate immunity. In: Janeway CA (ed) Immunobiology: the immune system in health and disease, Chap. 2, 5th edn. Garland Science, New York

27. Abbas AK, Lichtman AH (2003) Cellular and molecular immunology, 5th edn. Saunders, Philadelphia, p 563

28. Nguyen HX, Galvan MD, Anderson AJ (2008) Characterization of early and terminal complement proteins associated with polymorphonuclear leukocytes in vitro and in vivo after spinal cord injury. J Neuroinflamm 5:26

29. Mold C, Gewurz H, Du Clos TW (1999) Regulation of complement activation by C-reactive protein. Immunopharmacology 42(1-3):23-30

30. Celik I, Stover C, Botto M, Thiel S, Tzima S, Künkel D et al (2001) Role of the classical pathway of complement activation in experimentally induced polymicrobial peritonitis. Infect Immun 69(12):7304-7309

31. Ali YM, Lynch NJ, Haleem KS, Fujita T, Endo Y, Hansen S et al (2012) The lectin pathway of complement activation is a critical component of the innate immune response to pneumococcal infection. PLoS Pathog 8(7):e1002793

32. Biancone L, David S, Della Pietra V, Montrucchio G, Cambi V, Camussi G (1994) Alternative pathway activation of complement by cultured human proximal tubular epithelial cells. Kidney Int 45:451-460

33. Windbichler M, Echtenacher B, Hehlgans T, Jensenius JC, Schwaeble W, Männel DN (2004) Involvement of the lectin pathway of complement activation in antimicrobial immune defense during experimental septic peritonitis. Infect Immun 72(9):5247-5252

34. Hadders MA, Bubeck D, Roversi P, Hakobyan S, Forneris F, Morgan BP et al (2012) Assembly and regulation of the membrane attack complex based on structures of C5b6 and sC5b9. Cell Rep 1(3):200-207

35. Markiewski MM, Lambris JD (2007) The role of complement in inflammatory diseases from behind the scenes into the spotlight. Am J Pathol 171(3):715-727

36. Dunkelberger JR, Song WC (2010) Complement and its role in innate and adaptive immune responses. Cell Res 20(1):34-50
37. Liszewski MK, Kolev M, Friec GL, Leung M, Bertram PG, Fara AF (2013) Intracellular complement activation sustains $T$ cell homeostasis and mediates effector differentiation. Immunity 39(6): 1143-1157

38. Geha R, Rosen F (1996) Intravenous immunoglobulin therapy. In: Auston K, Burakoff S, Rosen FS, Strom T (eds) Therapeutic immunology. Blackwell Science, Cambridge, pp 280-296

39. Loirat C, Noris M, Fremaux-Bacchi V (2008) Complement and the atypical hemolytic uremia syndrome in children. Pediatr Nephrol 23(11):1957-1972

40. Hosler GA, Cusumano AM, Hutchins GM (2003) Thrombotic thrombocytopenic purpura and hemolytic uremic syndrome are distinct pathologic entities: a review of 56 autopsy cases. Arch Pathol Lab Med 127(7):834-839

41. Noris M, Caprioli J, Bresin E, Mossali C, Pianetti G, Gamba S et al (2010) Relative role of genetic complement abnormalities in sporadic and familial aHUS and their impact on clinical phenotype. Clin J Am Soc Nephrol 5(10):1844-1859

42. Caprioli J, Noris M, Brioschi S, Pianetti G, Castelletti F, Bettinaglio $\mathrm{P}$ et al (2006) International registry of recurrent familial HUS/TTP. Genetics of HUS: the impact of MCP, CFH, and IF mutations on clinical presentation, response to treatment, and outcome. Blood 108(4):1267-1279

43. Benz EJ Jr, Ebert BL (2012) Hemoglobin variants associated with hemolytic anemia, altered oxygen affinity, and methemoglobinemias. In: Hoffman R, Benz EJ Jr, Silberstein LE, Heslop HE, Weitz JI, Anastasi J (eds) Hoffman hematology: basic principles and practice, Chap 41, 6th edn. Churchill Livingstone Elsevier, Philadelphia

44. Noris M, Remuzzi G (2009) Atypical hemolytic-uremic syndrome. N Engl J Med 361(17):1676-1687

45. Sellier-Leclerc AL, Fremeaux-Bacchi V, Dragon-Durey MA, Macher MA, Niaudet P, Guest G et al (2007) Differential impact of complement mutations on clinical characteristics in atypical hemolytic uremic syndrome. J Am Soc Nephrol 18(8):2392-2400

46. Benz K, Amann K (2010) Thrombotic microangiopathy: new insights. Curr Opin Nephrol Hypertens 19(3):242-247

47. Tsai HM (2010) Pathophysiology of thrombotic thrombocytopenic purpura. Int J Hematol 91(1):1-19

48. Cazander G, Jukema GN, Nibbering PH (2012) Complement activation and inhibition in wound healing. Clin Dev Immunol. doi: $10.1155 / 2012 / 534291$

49. Qu H, Ricklin D, Lambris JD (2009) Recent developments in low molecular weight complement inhibitors. Mol Immunol 47(2-3):185-195

50. Suffritti C, Zanichelli A, Maggioni L, Bonanni E, Cugno M, Cicardi M (2014) High-molecular-weight kininogen cleavage correlates with disease states in the bradykinin-mediated angioedema due to hereditary $\mathrm{C} 1$-inhibitor deficiency. Clin Exp Allergy 44(12):1503-1514

51. Roos A, Nauta AJ, Broers D, Faber-Krol MC, Trouw LA, Drijfhout JW et al (2001) Specific inhibition of the classical complement pathway by C1q-binding peptides. J Immunol 167:7052-7059

52. Inal JM, Pascual M, Lesavre P, Schifferli JA (2003) Complement inhibition in renal diseases. Nephrol Dial Transplant 18(2):237-240

53. Höpken U (1997) Impaired inflammatory responses in the reverse arthus reaction through genetic deletion of the C5a receptor. J Exp Med 186:749-756

54. Nesargikar PN, Spiller B, Chavez R (2012) The complement system: history, pathways, cascade and inhibitors. Eur J Microbiol Immunol 2(2):103-111

55. Nandakumar KS, Andrén M, Martinsson P, Bajtner E, Hellström S, Holmdahl R et al (2003) Induction of arthritis by single monoclonal IgG anti-collagen type II antibodies and enhancement of arthritis in mice lacking inhibitory FcgammaRIIB. Eur J Immunol 33(8):2269-2277 
56. Ratajczak J, Reca R, Kucia M, Majka M, Allendorf DJ, Baran JT et al (2004) Mobilization studies in mice deficient in either $\mathrm{C} 3$ or $\mathrm{C} 3 \mathrm{a}$ receptor $(\mathrm{C} 3 \mathrm{aR})$ reveal a novel role for complement in retention of hematopoietic stem/progenitor cells in bone marrow. Blood 103:2071-2078

57. Haynes T, Luz-Madrigal A, Reis ES, Ruiz NPE, GrajalesEsquivel E, Tzekou A et al (2013) Complement anaphylatoxin $\mathrm{C} 3 \mathrm{a}$ is a potent inducer of embryonic chick retina regeneration. Nat Commun 4:2312. doi:10.1038/ncomms3312

58. Schraufstatter IU, Discipio RG, Zhao M, Khaldoyanidi SK (2009) C3a and C5a are chemotactic factors for human mesenchymal stem cells, which cause prolonged ERK1/2 phosphorylation. J Immunol 182:3827-3836

59. Heller T, Gessner JE, Schmidt RE, Klos A, Bautsch W, Kohl J (1999) Cutting edge: Fc receptor type I for IgG on macrophages and complement mediate the inflammatory response in immune complex peritonitis. J Immunol 162:5657-5661

60. Clynes R, Maizes JS, Guinamard R, Ono M, Takai T, Ravetch JV (1999) Modulation of immune complex-induced inflammation in vivo by the coordinate expression of activation and inhibitory Fc receptors. J Exp Med 189:179-185

61. Funabashi K, Okada N, Matsuo S, Yamamoto T, Morgan BP, Okada H (1994) Tissue distribution of complement regulatory membrane proteins in rats. Immunology 81:444-451

62. Atkinson C, Qiao F, Song H, Gilkeson GS, Tomlinson S (2008) Low-dose targeted complement inhibition protects against renal disease and other manifestations of autoimmune disease. J Immunol 180(2):1231-1238

63. Alexander JJ, Bao L, Jacob A, Kraus DM, Holers VM, Quigg RJ (2003) Administration of the soluble complement inhibitor, Crry-Ig, reduces inflammation and aquaporin 4 expression in lupus cerebritis. Biochim Biophys Acta 1639(3):169-176

64. Schifferli JA, Ng YC, Estreicher J, Walport MJ (1988) The clearance of tetanus toxoid/anti-tetanus toxoid immune complexes from the circulation of humans. Complement- and erythrocyte complement receptor 1-dependent mechanisms. J Immunol 140:899-904

65. Elvington M, Blichmann P, Qiao F, Scheiber M, Wadsworth C, Luzinov I et al (2014) A novel protocol allowing oral delivery of a protein complement inhibitor that subsequently targets to inflamed colon mucosa and ameliorates murine colitis. Clin Exp Immunol 177(2):500-508

66. Holers VM, Rohrer B, Tomlinson S (2013) CR2-mediated targeting of complement inhibitors: bench-to-bedside using a novel strategy for site-specific complement modulation. Adv Exp Med Biol 735:137-154

67. Tuveson DA, Ahearn JM, Matsumoto AK, Fearon DT (1991) Molecular interactions of complement receptors on B lymphocytes: a CR1/CR2 complex distinct from the CR2/CD19 complex. J Exp Med 173:1083-1089

68. Ricklin D, Lambris JD (2013) Complement in immune and inflammatory disorders: therapeutic interventions. J Immunol 190(8):3839-3847

69. Bruhns P, Samuelsson A, Pollard JW, Ravetch JV (2003) Colony-stimulating factor-1-dependent macrophages are responsible for IVIG protection in antibody-induced autoimmune disease. Immunity 18:573-581

70. Johansson AC, Sundler M, Kjellén P, Johannesson M, Cook A, Lindqvist AK et al (2001) Genetic control of collagen-induced arthritis in a cross with NOD and C57BL/10 mice is dependent on gene regions encoding complement factor 5 and Fc $\gamma$ RIIb and is not associated with loci controlling diabetes. Eur J Immunol 31:1847-1856

71. Mitchell DA, Taylor PR, Cook HT, Moss J, Bygrave AE, Walport MJ et al (1999) Cutting edge: C1q protects against the development of glomerulonephritis independently of $\mathrm{C} 3$ activation. J Immunol 162:5675-5679
72. Davis AE (2004) Biological effects of C1 inhibitor. Drug News Perspect 17(7):439-446

73. Barilla-LaBarca ML, Liszewski MK, Lambris JD, Hourcade D, Atkinson JP (2002) Role of membrane cofactor protein (CD46) in regulation of $\mathrm{C} 4 \mathrm{~b}$ and $\mathrm{C} 3 \mathrm{~b}$ deposited on cells. J Immunol 168(12):6298-6304

74. Huang Y, Qiao F, Abagyan R, Hazard S, Tomlinson S (2006) Defining the CD59-C9 binding interaction. J Biol Chem 281(37):27398-27404

75. Rehrig S, Fleming SD, Anderson J, Guthridge JM, Rakstang J, McQueen CE et al (2001) Complement inhibitor, complement receptor 1-related gene/protein $\mathrm{y}-\mathrm{Ig}$ attenuates intestinal damage after the onset of mesenteric ischemia/reperfusion injury in mice. J Immunol 167:5921-5927

76. Konrad Bork (2010) Diagnosis and treatment of hereditary angioedema with normal $\mathrm{C} 1$ inhibitor. Allergy Asthma Clin Immunol 6(1):15

77. Markovic SN, Inwards DJ, Frigas EA, Phyliky RP (2000) Acquired $\mathrm{C} 1$ esterase inhibitor deficiency. Ann Intern Med 132(2): 144-150

78. Askin G, Pusey CD (1999) Long term outcome after immunosuppression and plasma exchange for severe vasculitis associated with glomerulonephritis. J Am Soc Nephrol 10:101-109

79. Cicardi M, Zingale L, Zanichelli A, Pappalardo E, Cicardi B (2005) C1 inhibitor: molecular and clinical aspects. Springer Semin Immunopathol 27(3):286-298

80. Couser WG, Johnson RJ, Young BA, Yeh CG, Toth CA, Rudolph AR (1995) The effects of soluble recombinant complement receptor 1 on complement-mediated experimental glomerulonephritis. J Am Soc Nephrol 5(11):1888-1894

81. Khan MA, Nicolls MR, Surguladze B, Saadoun I (2014) Complement components as potential therapeutic targets for asthma treatment. Respir Med 108(4):543-549

82. Quigg RJ, He C, Lim A, Berthiaume D, Alexander JJ, Kraus D et al (1998) Transgenic mice overexpressing the complement inhibitor Crry as a soluble protein are protected from antibodyinduced glomerular injury. J Exp Med 188:1321-1331

83. Mauiyyedi S, Crespo M, Collins AB, Schneeberger EE, Pascual MA, Saidman SL et al (2002) Acute humoral rejection in kidney transplantation: II. Morphology, immunopathology, and pathologic classification. J Am Soc Nephrol 13:779-787

84. Levy M, Halbwachs-Mecarelli L, Gubler MC, Kohout G, Bensenouci A, Niaudet $\mathrm{P}$ et al (1986) $\mathrm{H}$ deficiency in two brothers with atypical dense intramembranous deposit disease. Kidney Int 30:949-956

85. Fukui A, Yuasa-Nakagawa T, Murakami Y, Funami K, Kishi N, Matsuda T et al (2002) Mapping of the sites responsible for factor I-cofactor activity for cleavage of $\mathrm{C} 3 \mathrm{~b}$ and $\mathrm{C} 4 \mathrm{~b}$ on human $\mathrm{C} 4 \mathrm{~b}$-binding protein $(\mathrm{C} 4 \mathrm{bp})$ by deletion mutagenesis. J Biochem 132(5):719-728

86. Mikata S, Miyagawa S, Iwata K, Nagasawa S, Hatanaka M, Matsumoto M et al (1998) Regulation of complement-mediated swine endothelial cell lysis by a surface-bound form of human C4b binding protein. Transplantation 65(3):363-368

87. Grumach AS, Leitão MF, Arruk VG, Kirschfink M, CondinoNeto A (2006) Recurrent infections in partial complement factor I deficiency: evaluation of three generations of a Brazilian family. Clin Exp Immunol 143(2):297-304

88. Sjöholm AG, Jönsson G, Braconier JH, Sturfelt G, Truedsson L (2006) Complement deficiency and disease: an update. Mol Immunol 43(1-2):78-85

89. Wang Y, Hu Q, Madri JA, Rollins SA, Chodera A, Matis LA (1996) Amelioration of lupus-like autoimmune disease in NZB/ W F1 mice after treatment with a blocking monoclonal antibody specific for complement component C5. Proc Natl Acad Sci USA 93:8563-8568 
90. Brodbeck WG, Kuttner-Kondo L, Mold C, Medof ME (2000) Structure/function studies of human decay-accelerating factor. Immunology 101(1):104-111

91. Kroshus TJ, Salerno CT, Yeh CG, Higgins PJ, Bolman RM 3rd, Dalmasso AP (2000) A recombinant soluble chimeric complement inhibitor composed of human CD46 and CD55 reduces acute cardiac tissue injury in models of pig-to-human heart transplantation. Transplantation 69(11):2282-2289

92. Cashman SM, Ramo K, Kumar-Singh R (2011) A non membrane-targeted human soluble CD59 attenuates choroidal neovascularization in a model of age related macular degeneration. PLoS ONE 6(4):e19078

93. Katschke KJ, Wu P, Ganesan R, Kelley RF, Mathieu MA, Hass $\mathrm{PE}$ et al (2012) Inhibiting alternative pathway complement activation by targeting the factor $\mathrm{D}$ exosite. J Biol Chem 287(16):12886-12892

94. Thomas TC, Rollins SA, Rother RP, Giannoni MA, Hartman SL, Elliott EA et al (1996) Inhibition of complement activity by humanized anti-C5 antibody and single-chain Fv. Mol Immunol 33:1389-1401

95. Kiener HP, Baghestanian M, Dominkus M, Walchshofer S, Ghannadan M, Willheim M et al (1998) Expression of the C5a receptor (CD88) on synovial mast cells in patients with rheumatoid arthritis. Arthritis Rheum 41:233-245

96. Arkin MR, Wells JA (2004) Small-molecule inhibitors of protein-protein interactions: progressing towards the dream. Nat Rev Drug Discov 3:301-317

97. Miwa T, Song WC (2001) Membrane complement regulatory proteins: insight from animal studies and relevance to human diseases. Int Immunopharmacol 1(3):445-459

98. Martí-Carvajal AJ, Anand V, Cardona AF, Solà I (2014) Eculizumab for treating patients with paroxysmal nocturnal hemoglobinuria. Cochrane Database Syst Rev 10:CD010340. doi:10.1002/14651858.CD010340.pub2

99. Dmytrijuk A, Robie-Suh K, Cohen MH, Rieves D, Weiss K, Pazdur R (2008) FDA report eculizumab (Soliris) for the treatment of patients with paroxysmal nocturnal hemoglobinuria. Oncologist 13(9):993-1000

100. Alexion Pharmaceuticals, Inc. (2012) Soliris (eculizumab) concentrated solution for intravenous infusion prescribing information. Springer International, Chesire, CT

101. Parker C (2012) Paroxysmal nocturnal hemoglobinuria. Curr Opin Hematol 19:141-148

102. FDA approves Soliris for rare pediatric blood disorder: Orphan drug receives second approval for rare disease", FDA, 23 September 2011, retrieved 25 December 2015

103. Hamad OA, Nilsson PH, Wouters D, Lambris JD, Ekdahl KN, Nilsson B (2010) Complement component C3 binds to activated normal platelets without preceding proteolytic activation and promotes binding to complement receptor 1 . J Immunol $184: 2686-2692$

104. Kasanmoentalib ES, Seron MV, Morgan BP, Brouwer MC, van de Beek D (2015) Adjuvant treatment with dexamethasone plus anti-C5 antibodies improves outcome of experimental pneumococcal meningitis: a randomized controlled trial. J Neuroinflamm 12:149

105. Mallet A, Hughes P, Szer J, Tuckfield A, Van Eps C, Cambell SB et al (2015) Atypical haemolytic uraemic syndrome treated with the complement inhibitor eculizumab: the experience of the Australian compassionate access cohort. Intern Med J 45:1054-1065

106. Gatault P, Brachet G, Ternant D, Degenne D, Récipon G, Barbet C et al (2015) Therapeutic drug monitoring of eculizumab: rationale for an individualized dosing schedule. mAbs 7(6):1205-1211

107. Risitano AM (2015) Complement inhibition for paroxysmal nocturnal hemoglobinuria: where we stand and where we are going. Expert Opin Orphan Drugs 3:691-704

108. Lee M, Wathier M, Love JA, McGeer E, McGeer PL (2015) Inhibition of aberrant complement activation by a dimer of acetylsalicylic acid. Neurobiol Aging 36(10):2748-2756

109. Salemi S, Markovic M, Martini G, D'Amelio R (2015) The expanding role of therapeutic antibodies. Int Rev Immunol 34:202-264

110. Benson MJ, Thomas NK, Talwar S, Hodson MP, Lynch JW, Woodruff TM et al (2015) A novel anticonvulsant mechanism via inhibition of complement receptor C5ar1 in murine epilepsy models. Neurobiol Dis 76:87-97

111. Risitano AM (2015) Current and future pharmacologic complement inhibitors. Hematol Oncol Clin North Am 29(3):561-582

112. Weinstock C, Möhle R, Dom C, Weisel K, Höchsmann B, Schrezenmeier $\mathrm{H}$ et al (2015) Successful use of eculizumab for treatment of an acute hemolytic reaction after ABO-incompatible red blood cell transfusion. Transfusion 55(3):605-610

113. Mastellos DC, Yancopoulou D, Kokkinos P, Huber-Lang M, Hajishengallis G et al (2015) Compstatin: a C3-targeted complement inhibitor reaching its prime for bedside intervention. Eur J Clin Invest 45:423-440

114. Risitano A (2015) Dissecting complement blockade for clinic use. Blood 125:742-744

115. Wong EKS, Goodship THJ, Kavanagh D (2013) Complement therapy in atypical haemolytic uraemic syndrome (aHUS). Mol Immunol 56:199-212

116. Varela JC, Brodsky RA (2013) Paroxysmal nocturnal hemoglobinuria and the age of therapeutic complement inhibition. Exp Rev Clin Immunol 9:1113-1124

117. Brennan FR (2014) Complement inhibitors in phase 1 and 2 clinical studies for immunological disorders. In: Reichert JM, Dübel S (eds) Handbook of therapeutic antibodies. Wiley-VCH Verlag GmbH \& Co. KGaA, Weinheim. doi:10.1002/9783527682423.ch37

118. Inhibition of Complement Activation (Eculizumab) in GuillainBarre Syndrome Study (ICA-GBS). https://clinicaltrials.gov/ct2/ show/study/NCT02029378. Accessed on 13/01/2016

119. Fitzpatrick AM, Mann CA, Barry S, Brennan K, Overell JR, Willison HJ (2011) An open label clinical trial of complement inhibition in multifocal motor neuropathy. J Peripher Nerv Syst 16(2):84-91

120. Weng WK, Levy R (2001) Expression of complement inhibitors CD46, CD55, and CD59 on tumor cells does not predict clinical outcome after rituximab treatment in follicular non-Hodgkin. Blood 98(5):1352-1357

121. Sjöberg AP, Trouw LA, Blom AM (2009) Complement activation and inhibition: a delicate balance. Trends Immunol 30(2):83-90

122. Diepenhorst GMP, van Gulik TM, Hack CE (2009) Complement-mediated ischemia-reperfusion injury: lessons learned from animal and clinical studies. Ann Surg 249(6):889-899

123. Ricklin D, Lambris JD (2008) Compstatin: a complement inhibitor on its way to clinical application. Adv Exp Med Biol 632:273-292

124. Vaisar T, Pennathur S, Green PS, Gharib SA, Hoofnagle AN, Cheung MC (2007) Shotgun proteomics implicates protease inhibition and complement activation in the antiinflammatory properties of HDL. J Clin Invest 117(3):746-756 